\title{
Taxonomy and ecology of Cornucoquimba ramosae sp. nov. (Ostracoda, Crustacea) on the Brazilian Equatorial shelf
}

\author{
J. C. COIMBRA ${ }^{1} \&$ D. A. DO CARMO ${ }^{2}$ \\ ${ }^{1}$ CECLIMAR - Universidade Federal do Rio Grande do Sul. Caixa Postal 11, CEP 95625-000. Imbé, RS, Brazil (e-mail: coimbra@if.ufrgs.br). \\ ${ }^{2}$ Instituto de Geociências. Universidade de Brasília. CEP 70910-900. Brasília, DF, Brazil (e-mail: derme@unb.br).
}

\begin{abstract}
Three species of Cornucoquimba Ohmert, 1968 are known from the Brazilian shelf: $C$. decorata, and C. nana in the north and northeast, and C. conulata in the south. An analysis of 339 samples collected between the international boundary at the Oiapoque river (Amapá State) and Cape São Roque (Rio Grande do Norte State), a distance of almost $1400 \mathrm{~km}$, has discovered a new species of this genus, C. ramosae sp. nov. It is restricted to the equatorial shelf and prefers biodetrital sand, from 15 to $67 \mathrm{~m}$ water depth. J. Micropalaeontol. 21(1): 23-27, May 2002.
\end{abstract}

\section{INTRODUCTION}

Three genera have been attributed to the subfamily Coquimbinae Ohmert, 1968: Coquimba, Nanocoquimba and Cornucoquimba, all described by Ohmert (1968). In Brazil, a preliminary study by Dias-Brito et al. (1988), which focused on the ecology of Recent ostracods and foraminifers from Sepetiba Bay (Rio de Janeiro State), mentioned the occurrence of Coquimba from marine biofacies. Later, taxonomic and zoogeographical studies on Recent occurrences of the Coquimbinae on the Brazilian continental margin were pioneered by Ramos (1994, 1996), who described several new species.

Three species of Cornucoquimba were described by Ramos (1996) and these include C. decorata, C. nana and C. conulata. Cornucoquimba decorata occurs from the northern coast of Amapá State $\left(04^{\circ} 39^{\prime} \mathrm{N} / 50^{\circ} 53^{\prime} \mathrm{W}\right)$ to the southern coast of Espírito Santo State $\left(22^{\circ} 46^{\prime} \mathrm{S} / 40^{\circ} 59.6^{\prime} \mathrm{W}\right)$, ranging in depth from 15 to $132 \mathrm{~m}$ and mainly associated with carbonate sand. The geographical distribution of $C$. nana is more restricted and the species is less abundant. It occurs from the southern coast of Maranhão State $\left(02^{\circ} 17^{\prime} \mathrm{S} / 42^{\circ} 07^{\prime} \mathrm{W}\right)$ to the northern coast of Espírito Santo $\left(20^{\circ} 39^{\prime} \mathrm{S} / 38^{\circ} 07^{\prime} \mathrm{W}\right)$, ranging in depth from 13 to $79 \mathrm{~m}$ and associated with carbonate sediment. Finally, $C$. conulata occurs from the southern coast of Espírito Santo $\left(19^{\circ} 59.4^{\prime} \mathrm{S} / 40^{\circ} 49.8^{\prime} \mathrm{W}\right)$ to the coast of Rio Grande do Sul State $\left(31^{\circ} 14^{\prime} \mathrm{S} / 49^{\circ} 31^{\prime} \mathrm{W}\right)$, ranging from 18 to $158 \mathrm{~m}$ in water depth and associated with terrigenous sediment. This last species clearly has different ecological requirements, as a result of its occurrence in the temperate water zone under influence of the Falklands Current.

\section{Brazilian continental margin}

The Brazilian continental margin is of passive type and is divided into three regions: Northern, known as the Equatorial margin, Cape Orange $\left(4^{\circ} \mathrm{N}\right.$ to $\left.51^{\circ} \mathrm{W}\right)$ to Cape São Roque (Rio Grande do Norte State), Eastern $\left(3^{\circ}\right.$ to $\left.24^{\circ} \mathrm{S}\right)$ and a southern $\left(24^{\circ} \mathrm{S}\right.$ to the international limit of Uruguay).

The material described here comes from the Brazilian Equatorial margin, which included the states of Amapá, Pará, Maranhão, Piauí, Ceará and Rio Grande do Norte (Fig. 1). For details on the sedimentology of the Equatorial margin it is necessary to consult Coimbra et al. (1999) and Martins \& Coutinho (1981).
Three major oceanographic currents strongly influence the Brazilian continental shelf. These are the Guyanas Current, Brazil Current and Falklands Current. The Guyanas and Brazil Currents are branches of the South Equatorial Current. The Guyanas Current flows northwards in the Equatorial margin while the Brazil Current flows southwards in the eastern and southern regions. In contrast to the tropical waters transported by the Guyanas and Brazil currents, the influence of the Falklands Current is restricted to the southern region. It is characterized by the movement of sub-Antarctic waters towards the southern Brazilian shelf margin (E. Boltovskoy, 1959; D. Boltovskoy, 1981; Do Carmo \& Sanguinetti, 1999).

\section{Material}

After the analysis of 339 samples collected during oceanographic cruises on the Equatorial margin, REMAC (legs 4, 5, 5A and 6) and GEOMAR (legs I, II and III), Cornucoquimba ramosae sp. nov. was only found in 12 samples, 11 from REMAC (legs 5 and 6) and one from GEOMAR (leg 1) (Table 1). The REMAC and GEOMAR projects were undertaken in the 1970s and 1980s by the Brazilian government for geological and oceanographical reconnaissance of the continental margin. These samples were collected using a Van Veen grab.

\section{TAXONOMY}

The type material is held in the collections of the 'Museu de Paleontologia', Universidade Federal do Rio Grande do Sul, Section of Ostracoda, to which the prefix MP-O of the type material refers. Supra-generic systematics follow Ohmert (1968) and Ramos (1994, 1996).

Suborder Podocopina Sars, 1866 Superfamily Cytheracea Baird, 1850

Family Hemicytheridae Puri, 1953

Subfamily Coquimbinae Ohmert, 1968

Genus Cornucoquimba Ohmert, 1968

\section{Cornucoquimba ramosae sp. nov.} (P1. 1, figs 1-6)

1992 Cletocythereis sp. Coimbra, Ramos \& Sanguinetti: 100, pl. 2, fig. 13.

1999 Cornucoquimba sp. Coimbra et al.: 371, pl. 2, fig. 12. 


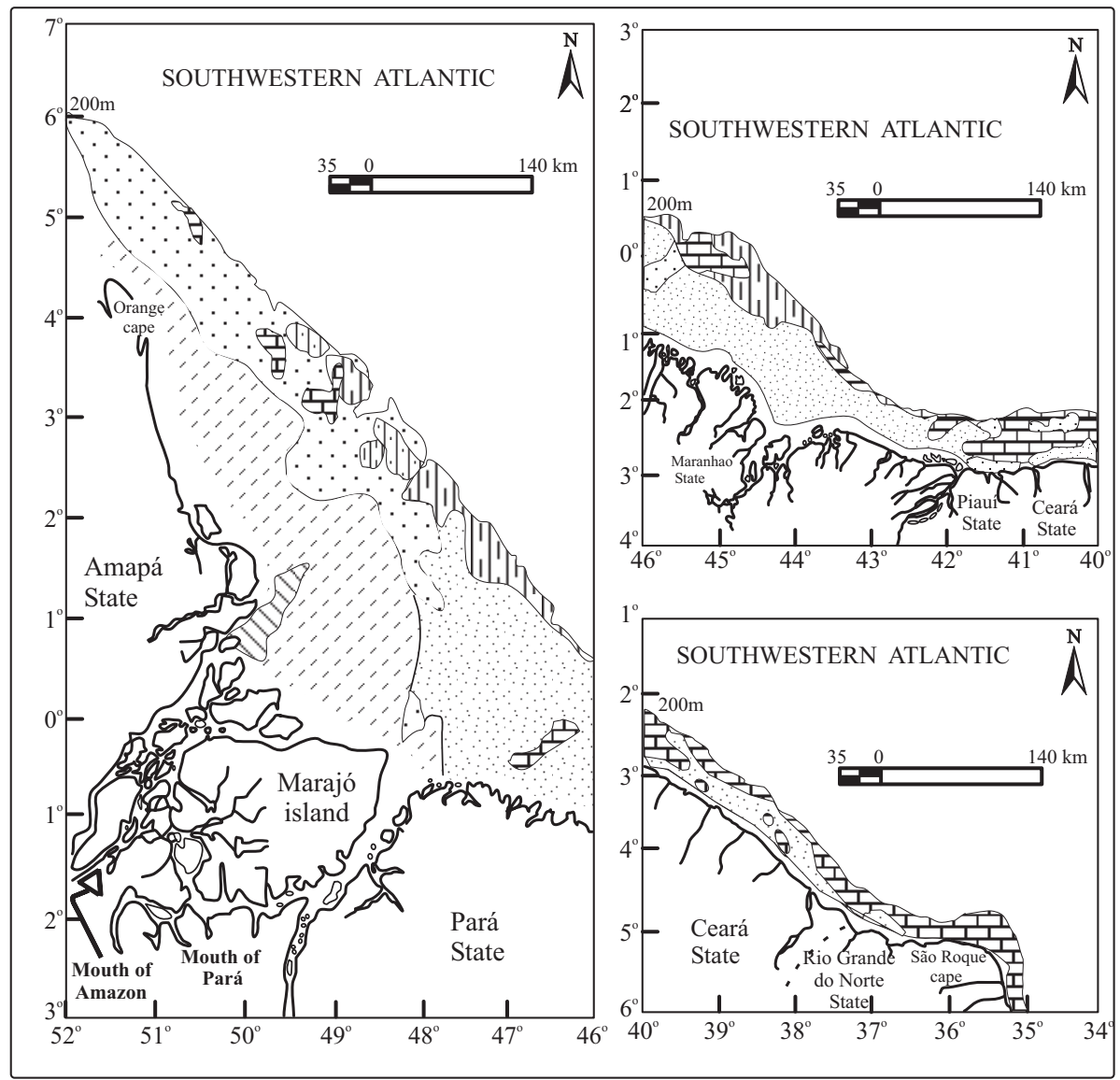

Legend

\$ Recent fluvial sand

$\because$ Recent fluvial mud

$\because \because$ Holocene fluvial reworked sand

Holocene reworked sand of indeterminated supplier
पा川 Holocene and Recent algal reef

†.T.T. Residual (Pleistocene?)

Holocene biodetritic sand and/or pebble reworked

Fig. 1. Sediment distribution in the Brazilian Equatorial margin (adapted from Kowsmann \& Costa, 1979).

Derivation of name. In honour of Dr Maria Inês Feijó Ramos, the first ostracodologist to study the zoogeography of the Subfamily Coquimbinae on the Brazilian continental margin.

Diagnosis. Surface strongly reticulate, as an irregular spongelike net pattern, with conspicuous ribs. The ventro-lateral rib is linked to the dorsal one through the posterior subvertical rib. Seven central muscle scars present, three frontal (the median subdivided) and four adductor scars (the upper median subdivided). Two dorsal scars usually present near to the central ones.

Holotype. Female, MP-O-1707, right valve, length $0.671 \mathrm{~mm}$, height $0.335 \mathrm{~mm}$.

Paratypes. Female, MP-O-1708, carapace, length $0.667 \mathrm{~mm}$, width $0.280 \mathrm{~mm}$. Male, MP-O-1709, right valve, length
$0.669 \mathrm{~mm}$, height $0.306 \mathrm{~mm}$. Male, MP-O-1710, carapace, length $0.678 \mathrm{~mm}$, width $0.235 \mathrm{~mm}$.

Material. 46 valves and 38 carapaces of adult and juvenile instars.

Type locality and horizon. REMAC, leg 6, sample 3683 $\left(02^{\circ} 28^{\prime} \mathrm{S} / 42^{\circ} 22^{\prime} \mathrm{W}, 20 \mathrm{~m}\right.$, biodetritic sand). Recent.

Description. Carapace sub-rectangular in lateral view. Right valve higher at the anterior cardinal angle. Dorsal margin straight and sloping backward; ventral margin concave in the oral region. Anterior margin well-rounded and denticulate; posterior margin with a postero-ventral denticulate caudal process. Eye tubercle fairly prominent. Surface strongly reticulate, forming a irregular sponge-like net. Dorsal rib sinuous and extending from the central dorsal area, subparallel to the dorsal 
Cornucoquimba ramosae sp. nov. (Ostracoda) from Brazil

\begin{tabular}{|c|c|c|c|c|c|c|}
\hline \multirow[b]{2}{*}{ Project } & \multirow[b]{2}{*}{ Sample } & \multirow[b]{2}{*}{ Coordinates } & \multirow[b]{2}{*}{ Depth (m) } & \multirow[b]{2}{*}{ Sedimentology } & \multicolumn{2}{|c|}{ No. specimens } \\
\hline & & & & & Carapaces & Valves \\
\hline \multirow[t]{3}{*}{ R. leg 5} & 3426 & $02^{\circ} 32^{\prime} \mathrm{S} / 40^{\circ} 00^{\prime} \mathrm{W}$ & 21 & Biodetritic sand & 02 & 04 \\
\hline & 3427 & $02^{\circ} 31^{\prime} \mathrm{S} / 40^{\circ} 09^{\prime} \mathrm{W}$ & 20 & Biodetritic sand & 02 & 06 \\
\hline & 3429 & $02^{\circ} 31^{\prime} \mathrm{S} / 40^{\circ} 27^{\prime} \mathrm{W}$ & 15 & Biodetritic sand & 03 & 02 \\
\hline \multirow[t]{8}{*}{ R. leg 6} & 3672 & $02^{\circ} 09^{\prime} \mathrm{S} / 42^{\circ} 15^{\prime} \mathrm{W}$ & 60 & Biodetritic sand & 04 & 05 \\
\hline & 3683 & $02^{\circ} 28^{\prime} \mathrm{S} / 42^{\circ} 22^{\prime} \mathrm{W}$ & 20 & Biodetritic sand & 01 & 03 \\
\hline & 3684 & $02^{\circ} 19^{\prime} \mathrm{S} / 40^{\circ} 21^{\prime} \mathrm{W}$ & 33 & Terrigenous sand & 03 & 00 \\
\hline & 3686 & $02^{\circ} 07^{\prime} \mathrm{S} / 40^{\circ} 28^{\prime} \mathrm{W}$ & 113 & Biodetritic sand & 03 & 05 \\
\hline & 3689 & $02^{\circ} 09^{\prime} \mathrm{S} / 41^{\circ} 06^{\prime} \mathrm{W}$ & 51 & Biodetritic sand & 05 & 02 \\
\hline & 3709 & $02^{\circ} 53^{\prime} \mathrm{S} / 39^{\circ} 28^{\prime} \mathrm{W}$ & 18 & Biodetritic sand & 05 & 10 \\
\hline & 3734 & $04^{\circ} 49^{\prime} \mathrm{S} / 36^{\circ} 08^{\prime} \mathrm{W}$ & 62 & Biodetritic sand & 07 & 03 \\
\hline & 3743 & $05^{\circ} 29^{\prime} \mathrm{S} / 35^{\circ} 10^{\prime} \mathrm{W}$ & 15 & Biodetritic sand & 01 & 04 \\
\hline G. leg 1 & 0008 & $02^{\circ} 04^{\prime} \mathrm{S} / 42^{\circ} 43^{\prime} \mathrm{W}$ & 67 & Biodetritic sand & 02 & 02 \\
\hline $\begin{array}{l}\text { Total no. } \\
\text { specimens }\end{array}$ & & & & & 38 & 46 \\
\hline
\end{tabular}

R, REMAC; G, GEOMAR

Table 1. Occurrences of Cornucoquimba ramosae sp. nov.

margin, to the posterio-dorsal hollow tubercle where it joins the subvertical rib. Subvertical rib extending obliquely forward to the end of the ventro-lateral rib where a second hollow tubercle occurs. Antero-marginal rim with some fossae. Another rim runs along the posterior margin and terminates in the posterior portion of the ventral region. Subcentral tubercle and the areas around it with different degrees of celation. Hinge holamphidont with crenulate postero-median element and posterior trilobate tooth. Line of concrescence and inner margin coincide throughout; extending parallel to the outer margin. Selvage strong and at some distance from the outer margin in the right valve, less distinct and subperipheral in the left. Several straight and simple marginal porecanals. Seven central muscle scars, three frontal (the median subdivided) and four adductor scars (the upper median subdivided). Two dorsal scars also occur. Sexual dimorphism conspicuous; in dorsal view, females clearly wider than males. In lateral view, males with dorsal margin less sloped.

Occurrence. Leg 5, samples 3426, 3427, 3429; leg 6, samples 3672, 3683, 3684, 3686, 3689, 3709, 3734, 3743; Geomar I, sample 08 .

Distribution. Recent, Brazilian Equatorial shelf, south of the mouth of the River Amazon.

Remarks. Cornocucoquimba ramosae sp. nov. is placed in this genus because of its characteristic central muscle scars and hinge pattern, as well as the two hollow tubercles present at posterior region. It differs from $C$. decorata Ramos, 1996 by its less inflated carapace and the strong subvertical rib that links to the ventro-lateral and dorsal ribs. There are also three frontal muscle scars in C. ramosae sp. nov. There is some external resemblance to Cletocythereis Swain, 1963. However, it differs from this Trachyleberididae genus by the frontal muscle scars that are typical of the Hemicytheridae.

\section{DISCUSSION AND CONCLUSIONS}

The occurrence of $C$. ramosae sp. nov. is restricted to the Brazilian Equatorial shelf from the southern coast of Maranhão
State $\left(02^{\circ} 04^{\prime} \mathrm{S} / 42^{\circ} 43^{\prime} \mathrm{W}\right)$ to near Cape São Roque on the coast of Rio Grande do Norte State $\left(05^{\circ} 29^{\prime} \mathrm{S} / 35^{\circ} 10^{\prime} \mathrm{W}\right)$. After consideration of the material studied by Ramos $(1994,1996)$ it was possible to conclude that this species does not occur in the southern region of the Brazilian continental shelf; it is a tropical water species.

As indicated by Coimbra et al. (1999), this species, together with 15 other ostracod species present in the Equatorial continental shelf, is restricted to the southeast of the mouth of the River Amazon and River Pará, suggesting that the discharge of these rivers might represent a barrier to its northward distribution. However, in contrast to the conclusion of those authors, this study shows a more restricted depth distribution for $C$. ramosae sp. nov., ranging from 15 to $67 \mathrm{~m}$ with an allochthonous occurrence at $113 \mathrm{~m}$. At this depth, the carapaces are eroded and covered with iron oxide indicating that they are relict specimens. This observation corroborates previous sedimentological studies carried out by several authors (Kowsmann \& Costa, 1979; Martins \& Coutinho, 1981).

Finally, the present authors are not certain that the three species of Cornucoquimba previously described by Ramos (1996) are autochthonous throughout their large depth range (15 to 158 m). As Ramos (1996) did not present data for the separation of autochthonous and allochthonous occurrences, the bathymetrical limits of $C$. decorata, $C$. nana and $C$. conulata could be due, in part, to reworked material. According to the ecological and palaeoecological data presented by Ohmert (1968), Yajima (1978), Ikeya \& Hanai (1982), Hu (1986), Hu \& Tao (1986), Paik \& Lee (1988), Coimbra et al.(1992, 1999), and this paper, the genus Cornucoquimba is most common at depths of less than $70 \mathrm{~m}$ and on sandy substrates. It is a stenohaline genus and since its origin in the Pliocene, is represented by more species in tropical than in temperate seas.

\section{ACKNOWLEDGEMENTS}

The first author thanks CNPq (Conselho Nacional de Desenvolvimento Científico e Tecnológico) for funding this research (process number 520309/99-5). For assistance with the figures the authors thank Luciana Tibiriça (Universidade de 


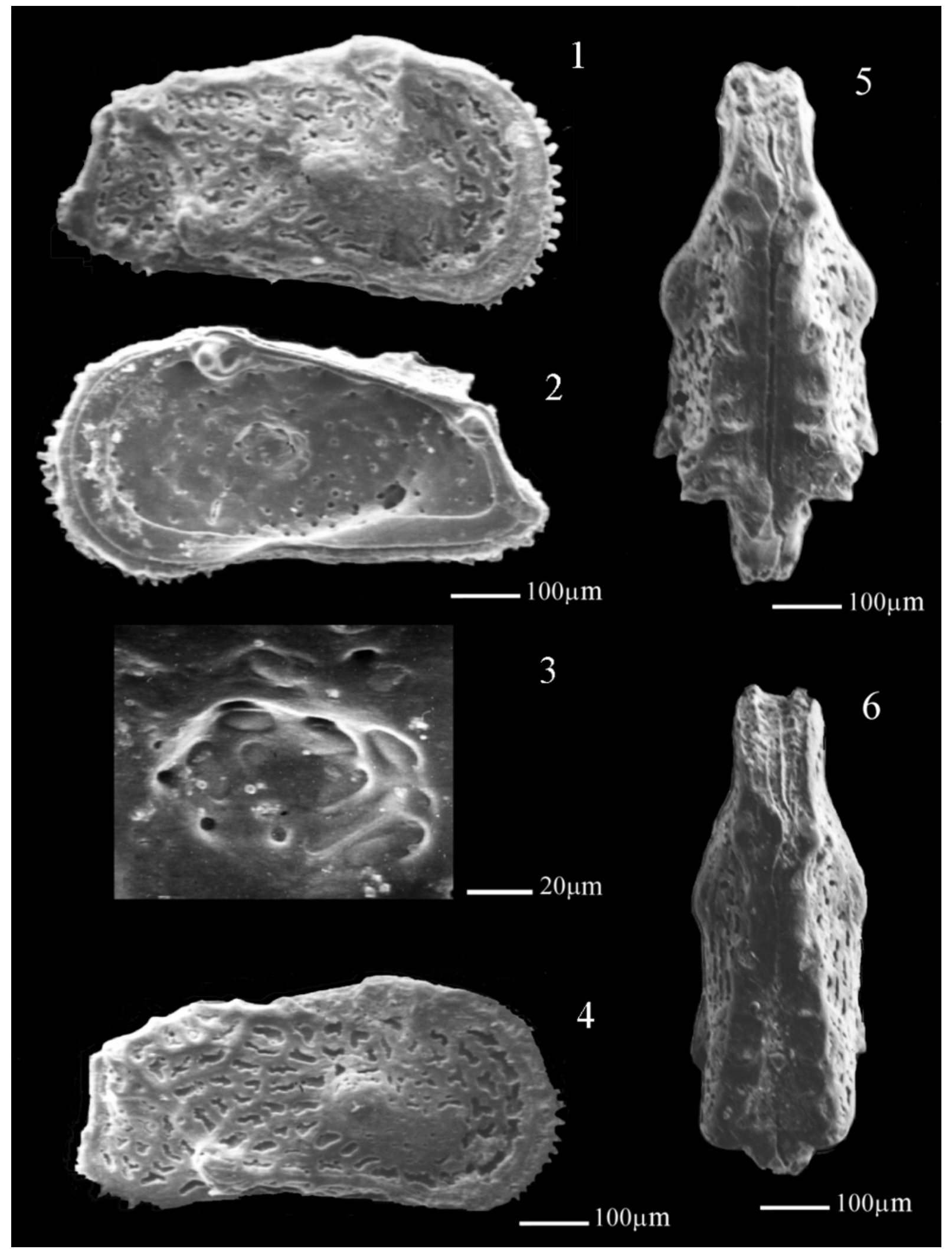

Explanation of Plate 1

Figs 1-6. Cornucoquimba ramosae sp. nov.: 1-3, holotype MP-O-1707, female, RV lateral view, (1) external view, (2) internal view, (3) detail of muscle scars; 4-6, paratypes (4) MP-O-1709, male, RV external view, (5) MP-O-1708, female carapace, dorsal view, (6) MP-O-1710, male carapace, dorsal view. 
Brasília). Two anonymous reviewers contributed with thoughtful comments on the manuscript and assisted with the English. Finally, for improvement of the English of an earlier manuscript the authors are grateful to Leanne Wilton (University of Wales).

\section{Manuscript received 29 July 2000 \\ Manuscript accepted 10 January 2002}

\section{REFERENCES}

Boltovskoy, D. 1981. Atlas del zooplancton del Atlántico Sudoccidental y métodos de trabajo con el zooplancton marino. UNIDEP (Publicación Especial), Mar del Plata 1-936.

Boltovskoy, E. 1959. La Corriente de Malvinas (un estudio en base a la investigación de foraminíferos). Ameghiniana, 16, 3-4: 357-389.

Chaves, H.A.F. 1983. Introdução Geral. Projeto Remac - Processos e Métodos. Relatório final. PETROBRÁS/SINTEC, Rio de Janeiro, $1-32$.

Coimbra, J.C., Ramos, M.I.F. \& Sanguinetti, Y.T. 1992. Sub-Recent ostracodes of the Tamandaré bay, Northeastern Brazil, a preliminary report on biofacies. Pesquisas, 1, 19: 94-105.

Coimbra, J.C., Pinto, I.D., Würdig, N.L. \& Do Carmo, D.A 1999. Zoogeography of Holocene Podocopina (Ostracoda) from the Brazilian equatorial shelf. Marine Micropaleontology, 37: 365-379.

Dias-Brito, D., Moura, J. \& Würdig, N. 1988. Relationship between ecological models based on ostracodes and foraminifers from Sepetiba bay (Rio de Janeiro - Brazil). In Hanai, T., Ikeya, N. \& Ishizaki, K. (Eds), Evolutionary Biology of Ostracoda its fundamentals and applications, 467-484. Kodansha, Tokyo.

Do Carmo, D.A. \& Sanguinetti, Y.T. 1995. Krithe occurrence on the Brazilian continental margin - an ecological approach. In Ríha, J. (Ed.), Ostracoda and Biostratigraphy, 407-412. Balkema, Rotterdam.
Do Carmo, D.A. \& Sanguinetti, Y.T. 1999. Taxonomy and palaeoceanographical significance of the genus Kritheostraroda in the Brazilian margin. Journal of Micropalaeontology, 18: 2, 111-123.

Hu, C.H. 1986. Pliocene ostracodes from Shoushan Kaohsing, Southern Taiwan. Petroleum Geology of Taiwain, 22: 103-125.

Hu, C.H. \& Tao, H.J. 1986. Fossil ostracodes from the Fengshan water reservoir, Kaohsiung district southern Taiwan. Acta Geologica Taiwanica, 24: 51-65.

Ikeya, N. \& Hanai, T. 1982. Ecology of Recent ostracodes in the Hamanako region, the Pacific coast of Japan. Bulletin of the University Museum of Tokyo, 20: 15-59.

Kowsmann, R.O. \& Costa, M.P.A. 1979. Sedimentação quaternária da margem continental brasileira e das águas oceânicas adjacentes. Projeto Remac - Reconhecimento global da margem continental brasileira, 8: PETROBRÁS, CENPES, DITEP, Rio de Janeiro, 1-55.

Martins, L.R. \& Coutinho, P.N. 1981. The Brazilian continental margin. Earth-Science Reviews, 17: 87-107.

Ohmert, W. 1968. Die Coquimbinae eine neue Unterfamilie der Hemicytheridae (Ostracoda) aus dem Pliozän von Chile. Mitteilungen der Bayerischen Staatssammlunge für Palaeontologie und Historische Geologie, 8: $127-165$

Paik, K.H. \& Lee, E.H. 1988. Plio-Pleistocene ostracodes from the Sogwipo Formation. In Hanai, T., Ikeya, N. \& Ishizaki, K. (Eds), Evolutionary Biology of Ostracoda its fundamentals and applications, 541-555. Kodansha, Tokyo.

Ramos, M.I.F. 1994. The ostracod genus Coquimba Ohmert, 1968 from the Brazilian continental shelf. Revista Española de Micropaleontología, 3, 24: 65-82.

Ramos, M.I.F. 1996. Taxonomy and zoogeography of the ostracod genera Nanocoquimba and Cornucoquimba Ohmert, 1968 from Recent sediments on the Brazilian continental shelf. Revista Española de Micropaleontología, 1, 28: 105-128.

Yajima, M. 1978. Quaternary Ostracoda from Kisarazu near Tokyo. Transactions Proceedings of the Paleontological Society of Japan, 112: 371-409. 